\title{
Pseudodiplodia cenangiicola sp. nov., a fungus on Cenangium ferruginosum
}

\author{
D.W. MINTER
}

MINTER, D.W. 1979: Pseudodiplodia cenangiicola sp. nov., a fungus on Cenangium ferruginosum. - Karstenia 19: 30-31.

A new coelomycete, Pseudodiplodia cenangiicola Nevodovsky ex Minter, on ascocarps of Cenangium ferruginosum Fr. ex Fr. (a fungus inhabiting pine twigs) is described from Krasnoyarsk, Siberia.

D.W. Minter, Commonwealth Mycological Institute, Ferry Lane, Kew, Surrey, England

Cenangium ferruginosum Fr. ex Fr. (Ascomycetes, Helotiales) is a common saprophyte on twigs of pines. Collections in the herbaria of the Royal Botanic Gardens, Kew (K) and the Commonwealth Mycological Institute, Kew (IMI) were recently examined and two specimens of an unusual collection from Krasnoyarsk (Siberia, U.S.S.R.) in October 1950 were discovered. They were labelled as Cenangium abietis (Pers.) Rehm (a synonym of $C$. ferruginosum), and formed no. 29 of the second fascicle of the exsiccata 'Griby SSSR', published in Moscow in 1954. On the label was included a Latin description of a new species, Microdiplodia cenangiicola Nevodovsky: 'Maculae nullae; pycnidiam in texturam apothecii alte demersa, ex cellulis dilute coloratis, solitaria, rare bini, trini confluentia, $120-270 \mu$ diam., portus simplex, sporae copiosae cinnamomeo-olivaceae, biloculares, ovoideae, vix vel non constrictae, $9-12 \times 4-6 \mu$.' An illustration was provided of the spores and the pycnidia as seen externally and in vertical section.

The Index of Fungi contains no record of this name, presumably because the description was so inconspicuous as to have been missed by the compilers. Further, the exsiccata was published in 1954, making Art. 31 of the International Code of
Botanical Nomenclature relevant. This states that 'the distribution on or after 1 Jan. 1953 of printed matter accompanying exsiccata does not constitute effective publication', with the proviso that 'if the printed matter is also distributed independently of the exsiccata, this constitutes effective publication'. Unless the terms of the proviso were met, therefore, Microdiplodia cenangiicola was not effectively, and hence not validly published. Examination of correspondence files at C.M.I. revealed that in 1956 an enquiry was made concerning the validity of other names published in the first fascicle of this series of exsiccata. The reply made it clear that while the new names of the first fascicle were effectively and validly published, there had been no independent distribution of the printed matter: 'G.S. Nevodovsky died (in 1952) before the first number of exsiccatae was published. It is why the new names of the described specimens are published only on the labels of the exsiccatae.' This clearly indicates that Microdiplodia cenangiicola was invalidly published. The fungus described by Nevodovsky is, however, undoubtedly present, and since it appears to be a new and rather unusual fungicolous species, it is redescribed and validated below. 


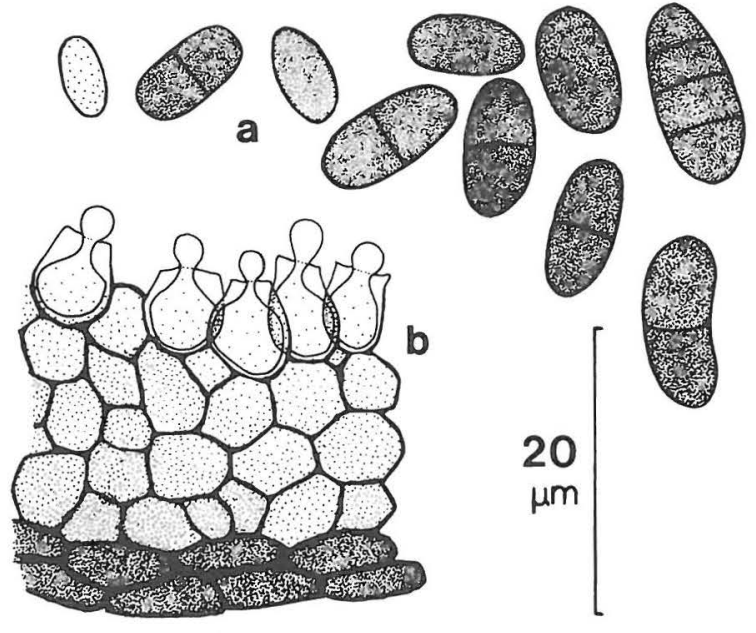

Fig. 1. Pseudodiplodia cenangiicola: a) conidia, b) conidiogenous cells and part of the pycnidium wall.

Pseudodiplodia cenangiicola Nevodovsky ex Minter, sp. nov.

= Microdiplodia cenangiicola Nevodovsky, Griby SSSR, fasc. 2, no. 29 (1954), nom. inval. (Article 31); as 'cenangicola'.

Conidiomata: pycnidia sunt, sparsa, singulatim (rarius bina vel terna) in ascocarporum textura Cenangii ferruginosi alte submersa, qui ipsi ex Pini virgis exoriuntur et minime praesens ob pycnidium adspectu differunt. Globosa sunt, $120-270 \mu \mathrm{m}$ diam, et ostiolata, parietem quaeque habentia $12-18 \mu \mathrm{m}$ et 4-6 cellulis altitudine, quarum exteriores obscurae et paulum complanatae videntur, texturam appropinquantes intricatam, sed interiores globosae et plus minusve hyalinae sunt, texturam habentes angularem. Conidiophori: absunt. Cellulae conidiogenae: monophialidicae sunt, et leves, hyalinae, plus minusve ampulliformes, 5-7 $\mu \mathrm{m}$ diam. Conidia: uniseptata, rarissime $2-3$ septata, tenuibus cum parietibus, levia, brunnea, elliptica (interdum paene cylindrica), $8-12 \times 4-6 \mu \mathrm{m}$ sunt, vix vel non constricta; sed prius matura quam sunt, plus minusve hyalina et aseptata sunt. - Type: Krasnoyarsk, U.S.S.R., in Cenangii ferruginosi apotheciis, A. Yavorski, Oct. 1950, IMI 63012, holotypus; $\mathrm{K}$, isotype.

Conidiomata: pycnidial, scattered, single (rarely in twos or threes), deeply immersed in the tissue of ascocarps of Cenangium ferruginosum arising from twigs of pine (the external appearance of the ascocarps scarcely altered by the presence of the pycnidia), globose, 120-270 $\mu \mathrm{m}$ diam, ostiolate, having a wall $12-18 \mu \mathrm{m}$ thick, $4-6$ cells deep, of which the outer cells are pigmented and rather flattened, approaching textura intricata, and the inner more or less globose and hyaline, of textura angularis. Conidiophores: absent. Conidiogenous cells: monophialidic, smooth, hyaline, more or less ampulliform, 5-7 $\mu \mathrm{m}$ diam. Conidia: 1-septate, or very rarely $2-3$-septate, thin-walled, smooth, brown, elliptical (sometimes almost cylindrical), 8-12 $\times$ 4-6 $\mu \mathrm{m}$, scarcely or not constricted at the septum. When immature, more or less hyaline and aseptate.

In the original description, Nevodovsky placed this species in Microdiplodia, a generic name which, according to Sutton (1977) is somewhat confused and in need of type studies. Subsequent studies by B.J. Dyko (unpublished) show that this name is not available for this fungus. Close examination of the conidium ontogeny of this species showed it to be phialidic, and as such, it is best placed under the earlier name Pseudodiplodia (Karsten) Sacc. (Saccardo 1884), a genus with simple pycnidia producing 1-septate pigmented spores from phialides, antedating by almost twenty years the first use of Microdiplodia.

Acknowledgement. The author wishes to thank Drs B.C. Sutton and D.L. Hawksworth for their advice on nomenclature and taxonomy.

\section{References}

Saccardo, P.A. 1884: Sylloge Fungorum 3. -860 pp. Patavii.

Sutton, B.C. 1977: Coelomycetes 6. Nomenclature of generic names proposed for Coelomycetes. Mycological Papers 141: 1-253. 